\title{
WAG, Rat Strain
}

National Cancer Institute

\section{Source}

National Cancer Institute. WAG, Rat Strain. NCI Thesaurus. Code C14414.

Tumors: medullary thyroid carcinoma $27 \%$, chromophobe adenoma of the pituitary $68 \%$, adrenal cortical adenoma $29 \%$, pheochromocytoma $2 \%$, islet cell adenoma $1 \%$. Mean life-span more than 31 months in females and 22 months in males (Boorman et al 1972). Mean life-span 31 months in females with pituitary tumors found in $69 \%$ of females. Other common tumors include medullary thyroid carcinoma 40\%, adrenal cortical adenoma 29\%, fibroadenoma of breast $21 \%$ with 19 other types of tumor found in 290 animals (Boorman and Hollander 1973). 